\title{
Wage trends in post-apartheid South Africa: Constructing an earnings series from household survey data*
}

\author{
Rulof Burger and Derek Yu, Department of Economics, Stellenbosch University
}

\section{Introduction}

Recent research on South African labour-market trends has suggested that workers have, on average, experienced a substantial decrease in their real wage earnings in the post-apartheid era. This paper will show that this claim is based on choosing datasets on either side of Statistics South Africa's changeover from the October Household Survey (OHS) to the Labour Force Survey (LFS), which caused a discontinuous and inexplicably large drop in average earnings. By using all the household datasets after 1994, one can attempt to identify and address the sources of data inconsistencies across surveys in order to construct a more comparable earnings time series. Taking account of the inconsistencies in questionnaire design and the presence of outliers, it is possible to construct a fairly stable earnings series for formal-sector employees. The data show an increase in real wage earnings in the post-transition period for formal-sector employees, and do not appear to provide strong evidence of decreasing wages in the informal economy. The paper also investigates the change in the distribution of earnings, as well as mean earnings trends by population group, gender and skill category.

\section{Comparability problems of the OHS and LFS earnings data}

Though it is widely accepted that the OHS and the LFS datasets cannot be easily compared, these difficulties are often overlooked when constructing a longer time series. A comparison of the average real monthly earnings ${ }^{1,2}$ of all workers in the 1995 OHS and September 2005 LFS datasets shows a decline from R3 558 to R2 744. This entails a 23-per-cent decrease in earnings, or an average decline of 2,6 per cent per annum, which is similar to the decline reported in Casale et al. ${ }^{3}$ (2005:10), though they acknowledge the problem of comparability when they warn that "part of the fall in average [informal-sector earnings] may be due to the more efficient capture of low-paid work" (2005:13). Figure 1.1 shows average real monthly earnings for each of the five OHS from 1995 to 1999 and the twelve LFSs from March 2000 to September 2005.

Figure 1.1 Average real monthly earnings at constant 2000 prices, $1995-2005$

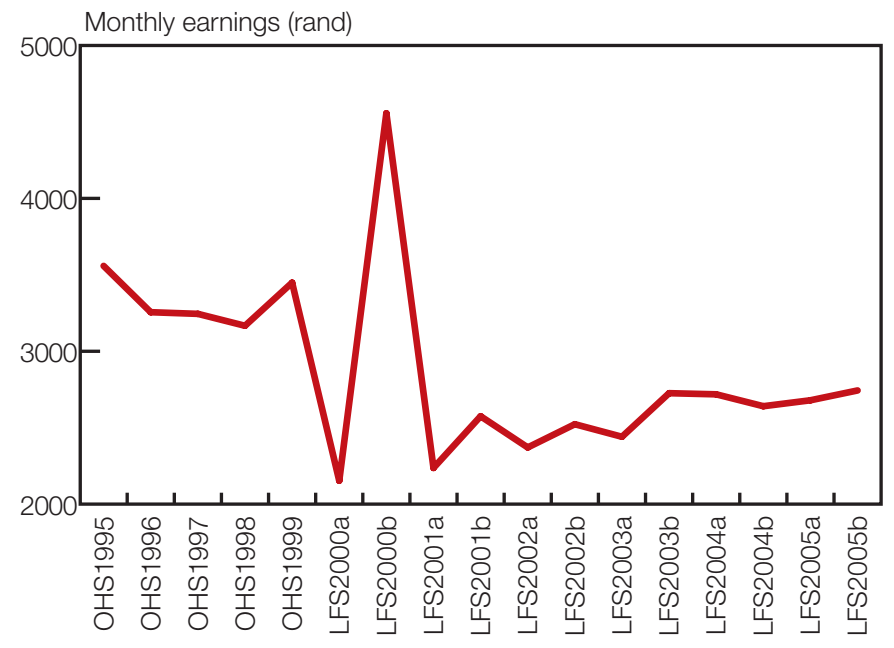

Source: Statistics South Africa and own calculations

* This paper draws on work funded by the Conflict and Governance Facility (CAGE). The authors are grateful for helpful comments by Ingrid Woolard, Ronelle Burger, Servaas van der Berg, Stan du Plessis and five referees. Any remaining errors are the responsibility of the authors.

1 Nominal earnings were converted into real earnings (expressed in 2000 prices) using the South African Reserve Bank's CPI series (KBP7032N). It was decided to use this series, rather than the non-agricultural GDP deflator, since it should provide a more accurate measure of changes in the purchasing power of workers.

2 For each survey, all respondents who reported an earnings interval only were used to estimate interval regressions of the log of the interval thresholds on a constant only. This provides estimates for the average and variance of the log of earnings distribution for interval reporters. Each observation was then assigned the mean value, conditional on falling within the reported interval, as its earnings. This method provides open-interval values that are less volatile between surveys than what was obtained using a Pareto distribution, but preliminary analysis indicates that statistical inference is not sensitive to the method used to address this issue. Von Fintel, D. 2006. Earnings Bracket Obstacles in Household Surveys - How Sharp are the Tools in the Shed? Stellenbosch Economic Working Paper 08/06, Stellenbosch University, Stellenbosch.

3 Casale, D, Muller, C and Posel, D. 2005. Two Million New Jobs: A Reconsideration of the Rise in Employment in South Africa, 1995 - 2003. DPRU Working Paper 05/97. Cape Town: Development Policy Research Unit. 
Using all the available surveys reveals that rather than being characterised by a steady decline, real wages were fairly stable over most of this period except for a 38-per-cent drop associated with Statistics South Africa's replacement of the OHS with the more consistent LFS. It is also clear that average earnings were dramatically higher in the September 2000 LFS than in the surveys directly preceding and following it.

\section{Outliers}

The problem of statistical inference with datasets containing outliers is well documented (Greene, 2003: 60, for example ${ }^{4}$ ). If the present analysis of wage trends is sensitive to the presence of certain observations and some of these are not representative of the underlying data generating process, then including the latter risks leads to misleading conclusions. This section will attempt to show that the mean earnings in certain years have indeed been very sensitive to the presence of a small number of highincome earners, some of whom may actually represent coding errors.

Table 1.1 displays the number (and unweighted proportion, in brackets) of observations with earnings above different threshold values in the different surveys. The first column reports the number of

Table 1.1: Number of observations falling above outlier thresholds

\begin{tabular}{|c|c|c|c|c|}
\hline & \multicolumn{4}{|c|}{ Observations } \\
\hline & All non-missing & > R83 334 pm & > R200 000 pm & $>\mathrm{R} 1000000 \mathrm{pm}$ \\
\hline 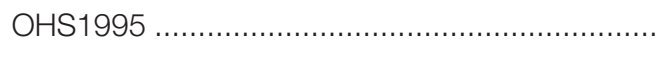 & 30855 & $\begin{array}{c}108 \\
(0,35 \text { per cent })\end{array}$ & $\begin{array}{c}11 \\
(0,04 \text { per cent })\end{array}$ & $\begin{array}{c}0 \\
(0,00 \text { per cent })\end{array}$ \\
\hline 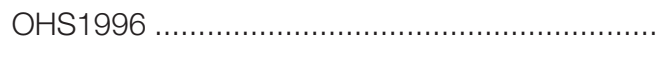 & 13751 & $\begin{array}{l}20 \\
(0,15 \text { per cent })\end{array}$ & $\begin{array}{c}0 \\
(0,00 \text { per cent })\end{array}$ & $\begin{array}{c}0 \\
(0,00 \text { per cent })\end{array}$ \\
\hline OHS1997 .... & 25462 & $\begin{array}{c}37 \\
(0,15 \text { per cent })\end{array}$ & $\begin{array}{c}3 \\
(0,01 \text { per cent })\end{array}$ & $\begin{array}{c}0 \\
(0,00 \text { per cent })\end{array}$ \\
\hline OHS1998 & 15887 & $\begin{array}{c}35 \\
(0,22 \text { per cent })\end{array}$ & $\begin{array}{c}1 \\
(0,01 \text { per cent })\end{array}$ & $\begin{array}{c}0 \\
(0,00 \text { per cent })\end{array}$ \\
\hline OHS1999 ....... & 22860 & $\begin{array}{c}46 \\
(0,20 \text { per cent })\end{array}$ & $\begin{array}{c}23 \\
(0,10 \text { per cent })\end{array}$ & $\begin{array}{c}3 \\
(0,01 \text { per cent })\end{array}$ \\
\hline$(\ldots \ldots \ldots \ldots \ldots \ldots \ldots \ldots \ldots \ldots$ & 9675 & $\begin{array}{c}3 \\
(0,03 \text { per cent })\end{array}$ & $\begin{array}{c}3 \\
(0,03 \text { per cent })\end{array}$ & $\begin{array}{c}0 \\
(0,00 \text { per cent })\end{array}$ \\
\hline 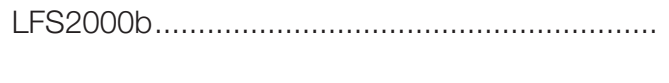 & 26801 & $\begin{array}{c}23 \\
(0,09 \text { per cent })\end{array}$ & $\begin{array}{c}15 \\
(0,06 \text { per cent })\end{array}$ & $\begin{array}{c}12 \\
(0,04 \text { per cent })\end{array}$ \\
\hline LFS2001a ..... & 27833 & $\begin{array}{c}5 \\
(0,02 \text { per cent })\end{array}$ & $\begin{array}{c}1 \\
(0,00 \text { per cent })\end{array}$ & $\begin{array}{c}1 \\
(0,00 \text { per cent })\end{array}$ \\
\hline 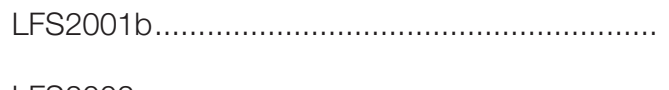 & 24441 & $\begin{array}{c}4 \\
(0,02 \text { per cent })\end{array}$ & $\begin{array}{c}1 \\
(0,00 \text { per cent })\end{array}$ & $\begin{array}{c}0 \\
(0,00 \text { per cent })\end{array}$ \\
\hline LFS2002a.... & 26459 & $\begin{array}{c}1 \\
(0,00 \text { per cent })\end{array}$ & $\begin{array}{c}0 \\
(0,00 \text { per cent })\end{array}$ & $\begin{array}{c}0 \\
(0,00 \text { per cent })\end{array}$ \\
\hline LFS2002b... & 23362 & $\begin{array}{c}2 \\
(0,01 \text { per cent })\end{array}$ & $\begin{array}{c}2 \\
(0,01 \text { per cent })\end{array}$ & $\begin{array}{c}0 \\
(0,00 \text { per cent })\end{array}$ \\
\hline 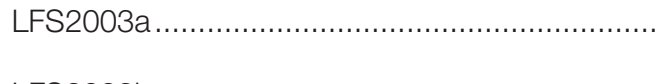 & 23209 & $\begin{array}{c}1 \\
(0,00 \text { per cent })\end{array}$ & $\begin{array}{c}0 \\
(0,00 \text { per cent })\end{array}$ & $\begin{array}{c}0 \\
(0,00 \text { per cent })\end{array}$ \\
\hline LFS2003b..... & 22564 & $\begin{array}{c}2 \\
(0,01 \text { per cent })\end{array}$ & $\stackrel{2}{2}(0,01$ per cent $)$ & $\begin{array}{c}0 \\
(0,00 \text { per cent })\end{array}$ \\
\hline LFS2004a ... & 22900 & $\begin{array}{c}1 \\
(0,00 \text { per cent })\end{array}$ & $\begin{array}{c}0 \\
(0,00 \text { per cent })\end{array}$ & $\begin{array}{c}0 \\
(0,00 \text { per cent })\end{array}$ \\
\hline LFS2004b........ & 23378 & $\begin{array}{c}1 \\
(0,00 \text { per cent })\end{array}$ & $\begin{array}{c}1 \\
(0,00 \text { per cent })\end{array}$ & $\begin{array}{c}0 \\
(0,00 \text { per cent })\end{array}$ \\
\hline LFS2005a ... & 24560 & $\begin{array}{c}0 \\
(0,00 \text { per cent })\end{array}$ & $\begin{array}{c}0 \\
(0,00 \text { per cent })\end{array}$ & $\begin{array}{c}0 \\
(0,00 \text { per cent })\end{array}$ \\
\hline LFS2005b... & 24625 & $\begin{array}{c}6 \\
(0,02 \text { per cent })\end{array}$ & $\begin{array}{c}1 \\
(0,00 \text { per cent })\end{array}$ & $\begin{array}{c}1 \\
(0,00 \text { per cent })\end{array}$ \\
\hline Total & 388622 & $\begin{array}{c}295 \\
(0,08 \text { per cent })\end{array}$ & $\begin{array}{c}64 \\
(0,02 \text { per cent })\end{array}$ & $\begin{array}{c}17 \\
(0,00 \text { per cent })\end{array}$ \\
\hline
\end{tabular}

Note: Threshold values are expressed at constant 2000 prices

4 Greene, W H. 2003. Econometric Analysis, 5th edition. New Jersey: Prentice Hall. 
employed who reported earnings for each survey. The next three columns show the number of observations that reported monthly (annual) real wage earnings exceeding R83 334 (R1 million), R200 000 (R2,4 million) and $\mathrm{R} 1$ million (R12 million).

Given the average real monthly earnings of R2 870 over the 1995 to 2005 period, these observations are all clearly far from representing "typical" South African wage earners. The third and fourth columns show evidence of high earning outliers, particularly for the $1999 \mathrm{OHS}$ and the September 2000 LFS. Even at the lowest outlier cut-off of R83 334, the share of these observations that comprise total wage earners is only 0,08 per cent in all periods, and never exceeds 0,35 per cent in any single period. Notwithstanding, excluding these outliers is successful in reducing much of the variability in the wage series, as demonstrated in Figure 1.2.

Figure 1.2 Average real monthly earnings at constant 2000 prices adjusted for outliers, $1995-2005$

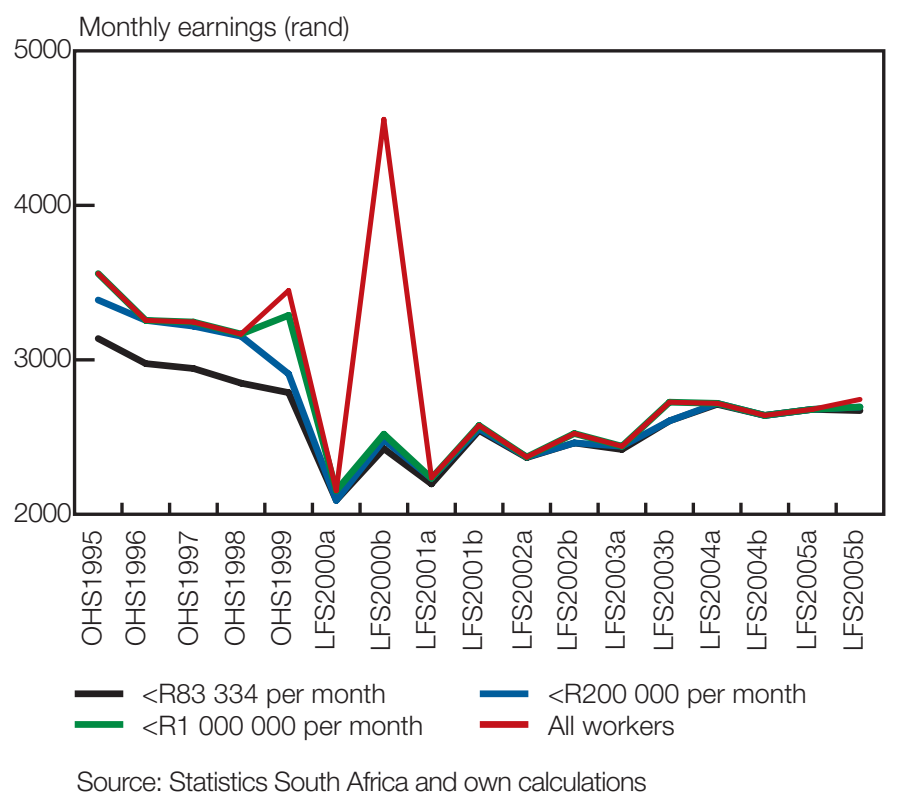

Omitting the 12 respondents who claimed to be receiving monthly earnings of more than $\mathrm{R} 1$ million in September 2000 reconciles the LFS for that period which had been so notably out of line - with the immediately preceding and subsequent surveys. Of the seventeen workers who claimed to be earning more than R1 million per month in all periods, ten were employed in semi-skilled and four in unskilled occupations, which raises the possibility that this is a problem of incorrect responses or coding errors rather than outliers. None of the other surveys are noticeably affected by the omission of these observations, except for a small drop in mean earnings in the 1999 OHS.

Moving to an outlier threshold of R200 000 per month only has a substantial impact on the average earnings in 1999 and, to a lesser extent, in 1995 and September 2003. When also excluding those workers earning more than R83 334 per month, this has a noticeable effect on the mean earnings of all the years before 2000, but on none of the years thereafter. This is mainly due to changes in the earnings intervals that individuals were allowed to specify without revealing their exact incomes, which permitted all workers in 1995 and the self-employed in 1996 to 1998 to answer in higher income brackets than were available to respondents in the subsequent years. For the remainder of the paper, only workers reporting monthly earnings of less than R83 334 will be included in the analysis.

Removing these outliers does not overturn the observation that wages declined between 1995 and 2005, although this fall is smaller than that of the unadjusted wage series ( 15 per cent compared to 23 per cent). The discontinuous drop in earnings during the five months between October 1999 and March 2000 is still present, although somewhat smaller (25 per cent compared to 38 per cent).

\section{Inconsistent capturing of employment}

Measuring informal-sector activities is notoriously difficult, but the increasing efficiency with which informal employment has been captured in the household surveys since the earliest OHS has received much attention (see for example Devey et al. ${ }^{5}, 2003: 12$, and Casale et al., 2005:3). Although we do not attempt to provide a comprehensive description of changes to the questions asked by Statistics South Africa in order to distinguish between the employed, the unemployed and the inactive, it is indicative of the increased effort to capture low-paid workers to look briefly at the first question asked by fieldworkers to determine the labourmarket status of respondents. 
In 1995 and 1996, respondents were asked "what [they did] most during the preceding 7 days", and were allowed to choose between "working full-time" and "working part-time" as answers. For the 1997 and 1998 surveys, a third alternative, "casual worker", was added to the questionnaire and 1999 also specified "seasonal worker" as an option. Starting in 2000, respondents were asked whether they engaged in any one of a number of specific, mostly low-income activities (e.g. "guarding cars" or "making things for sale"). If a substantial share of workers did not perceive themselves to be employed full-time or parttime, but were rather involved in casual or seasonal employment or any of the other categories added since 2000, then one would expect the surveys to show an increase in the employment of low-income earners between 1995 and 2000, combined with an associated decrease in the average earnings of all captured workers. But this apparent rise in lowincome employment and the associated decrease in average earnings are both statistical artifacts, produced by changes in the sampling method.

Figure 1.3 compares the share of informal-sector workers $^{6}$ comprised of total employment with average real monthly informal-sector earnings. Informal-sector employment increased from about 5 per cent of total employment in 1995 and 1996 (during which years only the self-employed were classified as informal-sector workers) to 14 per cent in 1997 and 1998 and continued on this upward trend, before stabilising at a share of around 21 per cent after 2001. Average informal wage earnings decreased dramatically between 1995 and 2000, the years during which the improved capturing of low-income workers occurred, but have been stable since 2000. Although it is possible that South Africa experienced an increase in the size of its informal sector between 1995 and 2000 and that this induced a decrease in informal-sector earnings, the magnitudes of these shifts are such as to suggest that the observed trends are mainly driven by Statistics South Africa's improved ability to capture low-paying informal activities during the OHS years.

The likely classification of a large proportion of lowearning informal-sector workers as unemployed or inactive in the earlier surveys means that the average informal-sector wage would have been upwardly biased for these years. Unfortunately there does not seem to be a way to adjust the earlier surveys in order to create a comparable earnings series going back to 1995 for the informal sector or, by extension, for the whole economy. However, it is possible that a comparable formal-sector wage series can be obtained by excluding informal-sector workers.

\section{Figure 1.3 Informal-sector real monthly earnings at constant 2000 prices and share of total employment, 1995 - 2005}



Source: Statistics South Africa and own calculations

In Figure 1.4 the average monthly earnings and the employment share of the self-employed are compared. Since roughly two-thirds of informal-sector workers are also self-employed, there are many similarities between Figures 1.3 and 1.4. Again, the increase in the self-employed share of total employment between 1995 and 2000 is implausibly large, and probably reflects the improved capturing of low-paid self-employed workers. Furthermore, the 70per-cent drop in self-employed earnings during the five months between October 1999 and March 2000 (combined with an 11-percentage-point increase in their employment share) is the main reason for the discontinuous decrease in earnings associated with the introduction of the labour force surveys. Following this discontinuity, the earnings of the self-employed have, on balance, increased substantially.

6 This includes those working in subsistence agriculture, since their employment share and average earnings suffer from the same inconsistencies as those of the rest of the informal sector. Using information on the worker's occupation, it is possible to identify domestic workers in a more or less consistent manner between 1995 and 2005. This claim appears to be verified by the relative stability of the employment share and earnings for this group over time. Since we are interested in constructing an earnings series that is as representative of the labour force as possible, domestic workers are not excluded together with the other informal-sector workers. Although it deviates from the usual and correct use of the term, for the sake of convenience "formal sector" will henceforth also include domestic workers. 
Figure 1.4 Self-employed real monthly earnings at constant 2000 prices and share of total employment, 1995 - 2005

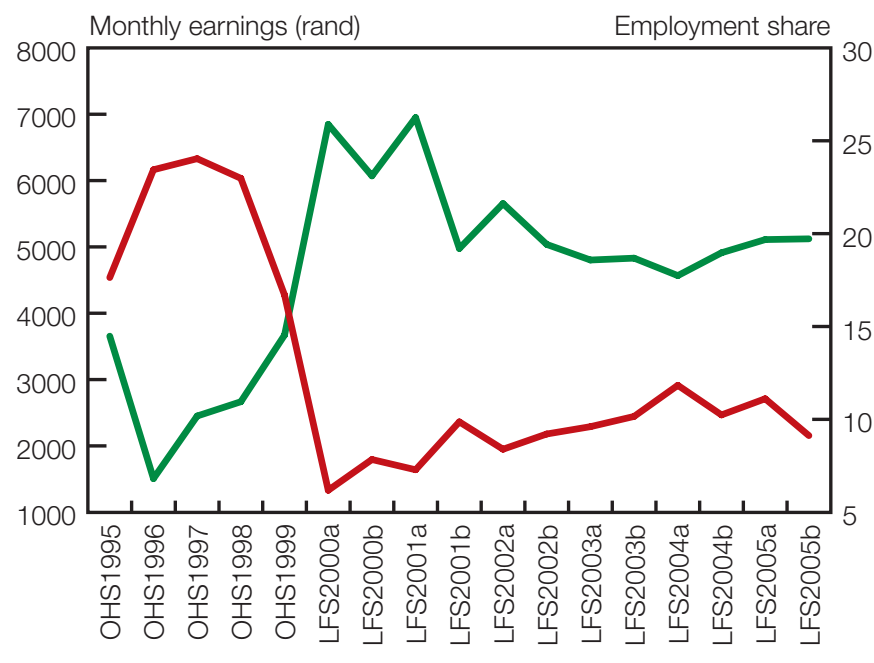

- Earnings

- Share of total employment

Source: Statistics South Africa and own calculations

Figure 1.5 compares the wage series for all workers (excluding those reporting monthly earnings of more than R83 334) to the wage series for formal-sector workers only (both employers and employees), all employees (in contrast to the self-employed) and formal-sector employees. Excluding the informal sector entails an upward adjustment in wages, and removes about half of the discontinuous fall in wages between 1999 and 2000. Removing only the selfemployed, however, has the effect of decreasing the average earnings for the OHS years, but increasing it in the early LFS years, and yields a relatively smooth wage series without any large discontinuities. Excluding both the self-employed and the informal sector provides a wage trend for formal-sector employees, which is relatively stable over time. Instead of showing a 23-per-cent decrease in wages between 1995 and 2005, this series suggests that average earnings were marginally higher (4 per cent) in September 2005 than in October 1995.

Pooling the March and September rounds of the LFS into a single annual observation also reduces some of the series' volatility (average earnings are usually slightly higher in the September than in the March
Figure 1.5 Average real monthly earnings at constant 2000 prices by type of employment, 1995 - 2005

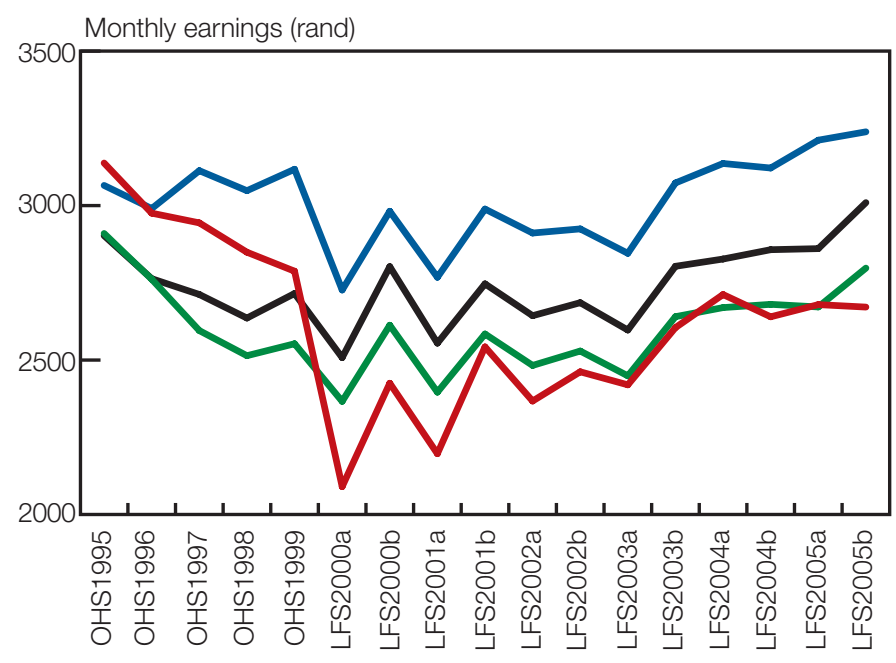

All workers
Excluding informal sector

Excluding self-employed Excluding informal sector and self-employed

Source: Statistics South Africa and own calculations

rounds). This annual series indicates that the earnings of formal-sector employees declined by 9 per cent between 1995 and 1998, but then increased by 11 per cent between 1998 and 2005. Figures 1.3 and 1.4 also reveal that except for the fall in average earnings associated with the improved capturing of low-income workers, there is no indication that average earnings have actually decreased for informal-sector workers or the self-employed since 2000.

Despite comparability issues, Figure 1.6 compares the growth in the national accounts series total compensation of employees as reported in the South African Reserve Bank's Quarterly Bulletin, to that derived from the household surveys (after excluding outliers, the selfemployed and informal-sector workers). The national accounts series refers to the annual growth rate in KBP6000J, deflated by KBP7032J. It is more comparable and smoother, and uses information from more sources than just the Survey of Employment and Earnings (SEE). The two series are very different prior to 1998, but fairly similar between 1998 and 20057,. The post-1998 trend of the constructed household survey earnings series therefore seems to be corroborated by an independent data source.

7 This is not true for the level of total earnings, which is much lower in the household surveys than in the national accounts series.

8 The convergence of the two trends after 1998 could be due to the greater consistency in the sampling method used by the more recent household surveys. 
Figure 1.6 Growth in total real remuneration of employees, $1995-2005$

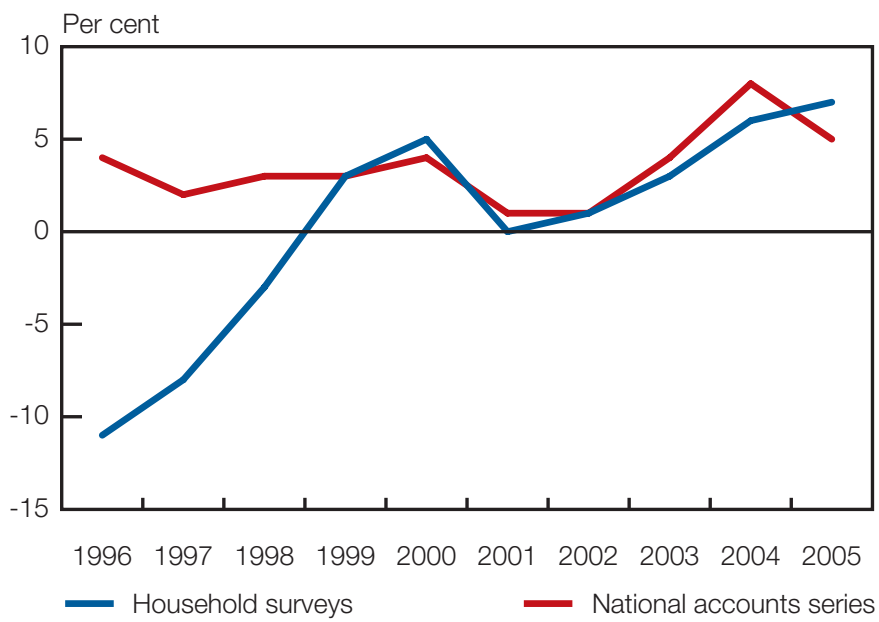

Source: South African Reserve Bank; and own calculations

\section{The change in the earnings distribution}

The previous sections looked only at changes in mean earnings, but for many purposes - investigating the impact of labour-market trends on poverty, for instance - changes in the distribution of earnings are equally important. Figure 1.7 displays the distribution of real earnings (on a log scale) in 1995, 1998 (the year in which average real earnings appear to have bottomed out), and 2005. Between 1995 and 1998 the data show a leftward shift in the earnings distribution, which is also reflected in the decreasing average earnings over this period (shown in Figure 1.5). It can be observed that this decrease was partly the result of a decline in the share of very high income earners, but was mainly driven by a large increase in the density at the lower end of the earnings distribution. The household surveys suggest that the proportion of formal-sector employees earning less than R600 per month nearly doubled from 11 per cent to 19 per cent over this period.

In addition to the decrease in average earnings, the household surveys therefore suggest that the period between 1995 and 1998 was also characterised by a worsening in the distribution of earnings. This trend was reversed after 1998, however, as the data show a decline in the density at the very bottom of the distribution, but an increase in the proportion of employees just above this lowest category: The share of workers earning less than R400 per month decreased from 14 to 8,5 per cent, while the percentage of those earning between R400 and
R1 200 increased from 22 to 31 per cent. It follows that except for the increase in mean earnings, many of the very lowest formal-sector wage earners must have experienced an increase in their incomes between 1998 and 2005.

Figure 1.7 Distribution of formal-sector real monthly earnings at constant 2000 prices (log scale)

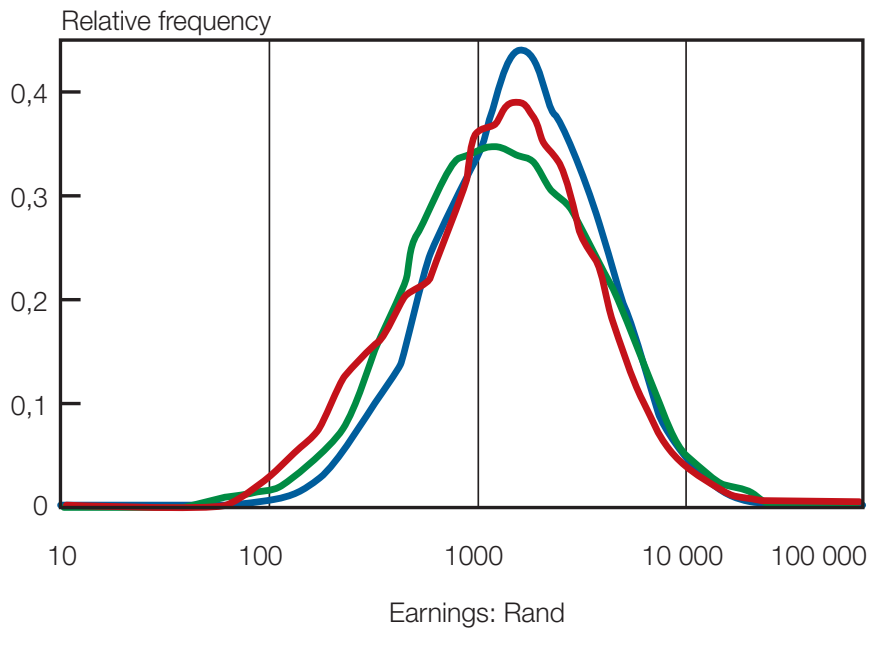

- OHS $1995 \quad$ OHS 1998

LFS 2005*

* LFS a+b combined

Source: Statistics South Africa and own calculations

\section{Wage trends in the post-transition period}

The preceding sections showed how a comparable earnings series can be derived from the household surveys by excluding outlier observations, the selfemployed and informal-economy workers. This series can now be used to investigate post-transition wage trends (for formal-sector employees earning less than a million rand per year), by population group, gender and skill category. Figure 1.8 compares the average real monthly earnings for each of South Africa's population groups, and shows that all four groups experienced an increase in real wages between 1995 and 2005, although the increase was smaller for Africans than it was for the other three racial categories. The average earnings of Whites increased relative to that of the other population groups over the period as a whole, but since 2003 their earnings have shown a small decrease whereas those of African and Coloured workers increased by 16 and 18 per cent, respectively. 
Figure 1.8 Average formal-sector real monthly earnings at constant 2000 prices by population group, $1995-2005$

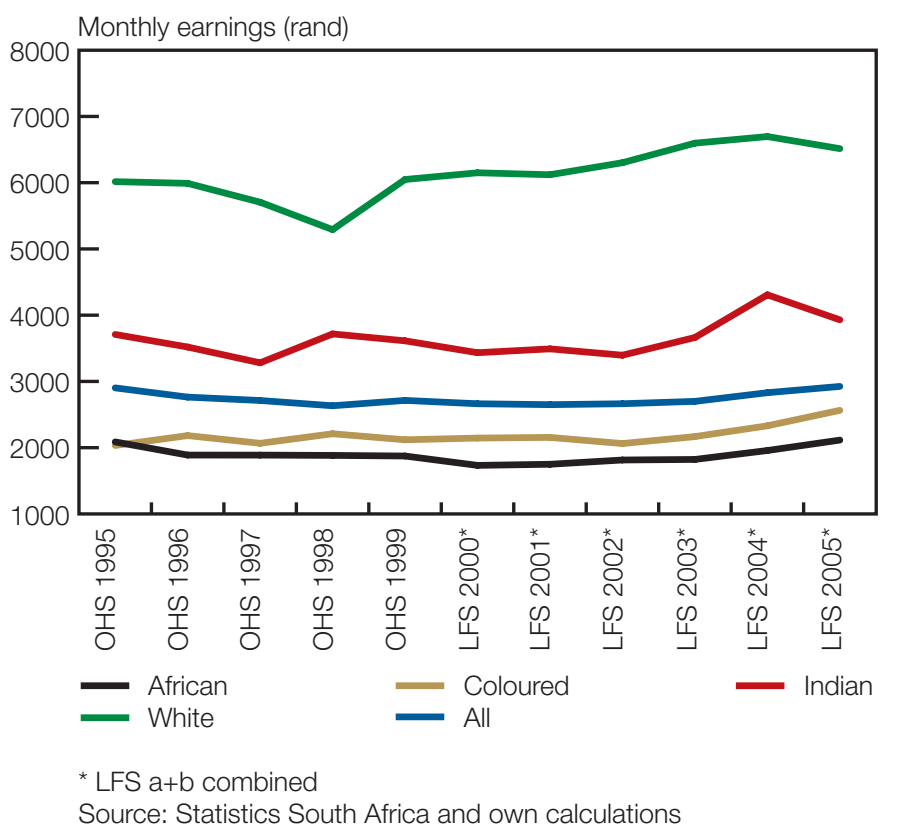

The wage trends for male and female workers are presented in Figure 1.9. Women experienced a sharper fall in their earnings between 1995 and 1998, so that by 2005 average female earnings were still slightly below the 1995 level, whereas average male earnings were about 5 per cent higher. The relative earnings differential increased over the period as a whole, although there has been a narrowing of the gender wage gap since 2000 .

Figure 1.10 reveals the earnings trends for workers employed in the different skill categories ${ }^{9}$. Evidently, the earnings of unskilled and semi-skilled workers were slightly lower in 2005 than they were in 1995, whereas skilled earnings increased substantially over the same period. This is consistent with what one would expect to see in an economy with a shortage of skilled labour and an abundance of lowskilled unemployed ${ }^{10}$. After a large decrease in their earnings between 1995 and 2002, the wages of unskilled workers increased by 27 per cent between 2002 and 2005, whereas the earnings growth of the highly skilled appear to have slowed down. One of the factors which may have contributed to the higher unskilled wages is the broadening of minimum wage legislation.

The post-transition period as a whole therefore appears to be characterised by increasing inequality
Figure 1.9 Average formal-sector real monthly earnings at constant 2000 prices by gender, 1995 - 2005

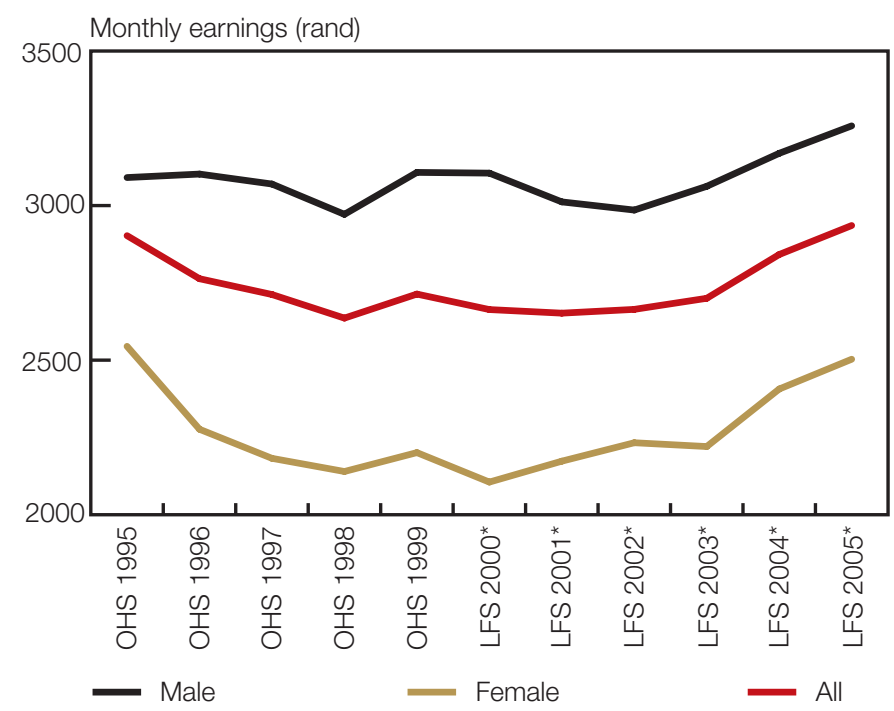

* LFS a+b combined

Source: Statistics South Africa and own calculations

between groups, with little gains of the average wage increase accruing to women, the non-white population groups, or unskilled workers. Somewhat more optimistically, it seems that the accelerating growth

Figure 1.10 Average formal-sector real monthly earnings at constant 2000 prices by occupation, $1995-2005$

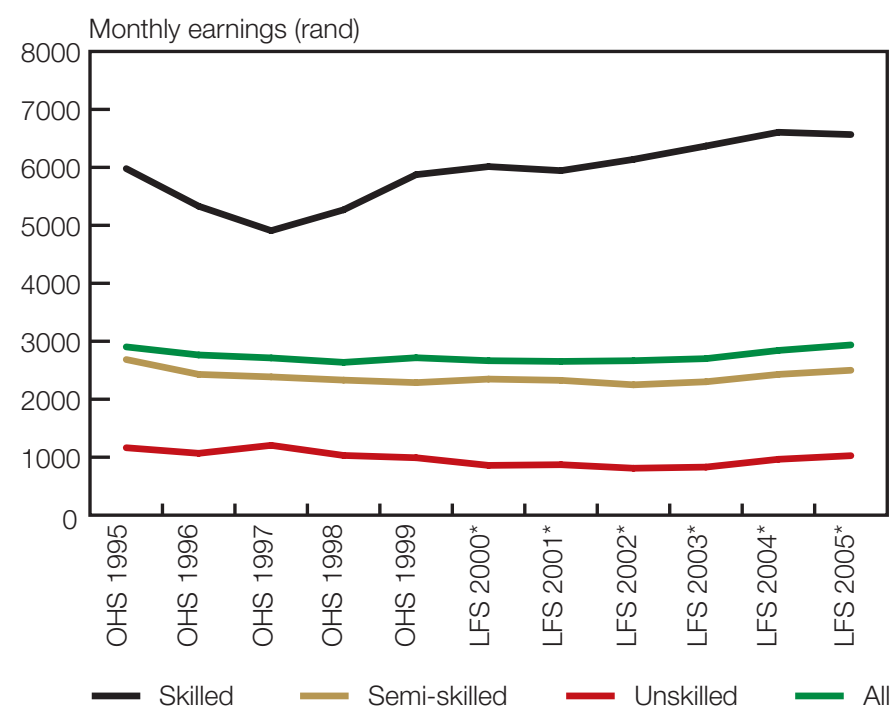

* LFS a+b combined

Source: Statistics South Africa and own calculations

9 "Unskilled" refers to workers employed in ISCO category 9 as well as domestic workers, "semi-skilled" refers to those in categories 4 - 8 and "skilled" refers to those in categories $1-3$.

10 Altman, M. 2005. Wage Trends and Dynamics in South Africa. Review of Labour Markets in South Africa. Pretoria: Human Sciences Research Council. 
experienced by the country since 2000 may recently have started to trickle down to low-income earners. The racial earnings gap has been narrowing since 2003, whereas the gender gap has been narrowing since 2000.

\section{Conclusion}

This paper attempts to show that by addressing certain obvious shortcomings in the household survey datasets, it is possible to construct a wage series which is fairly stable over time and for which the trend is broadly supported by data from the SEE (at least from 1998 onwards). It also shows that claims of declining real wages in the post-apartheid years rely crucially on choosing surveys on either side of the 1999 - 2000 discontinuous decrease in earnings. Such claims therefore implicitly accept that the dramatic drop in informal and particularly selfemployed earnings between October 1999 and March 2000 is a true reflection of what occurred in the South African labour market rather than representing a change in Statistics South Africa's sampling or questionnaire design.
This paper constructs a wage series for South African formal-sector employees (as well as domestic workers) earning less than R1 million per year, and demonstrates that the real earnings for these workers showed a small increase over the 1995 to 2005 period. Except for unrealistically large decreases in earnings which were associated with the improved capturing of low-income earners between 1995 and 2000, the earnings of informal-sector workers and the self-employed appear to have been fairly stable. Between 1995 and 1998 the household surveys suggest that South African workers experienced a decrease in their real earnings, although the remaining inconsistencies for these years could cast some doubt over at least the magnitude of this decline. After 1998 average earnings started to increase, and this period was also marked by an improvement in the distribution of earnings. Although the post-transition period as a whole did not show any improvements in the relative earnings position of women, the non-white population groups or unskilled and semi-skilled workers, there are signs that there has been a decrease in group inequality in more recent years. 